\title{
Performance of Decentralized Local Service Delivery in Developed Countries: Case Study of Japan
}

\section{Priyantha W. Mudalige}

Senior Lecturer, Department of Political Science, Faculty of Social Sciences, University of Kelaniya, Dalugama, Sri Lanka, Ph.D. Candidate, Graduate School of Science and Engineering, Saga University, Honjo-machi, Saga, Japan

Submitted: 26 September 2020

Accepted: 04 December 2020

Published: 31 December 2020

Corresponding author:

Priyantha W. Mudalige

DOI: 10.19044/esj.2020.v16n35p40

(c) Copyright 2020 Mudalige P. W. Distributed under Creative Commons BY-NC-ND 4.0 OPEN ACCESS
Abstract
Many countries decentralize the administrative, fiscal, and political functions of the central government to lower-level governments. In many developing and developed countries, governments and their policymakers have used decentralization as a means of improving the delivery of local service. Accordingly, this study is based on the delivery of local services to the people by the local governments of Japan as a developed country. The overall objective of this article is to review the performance of decentralized local service delivery in developed countries and based on a case study of Japan. The study also aims to examine the correlation between the revenue and expenditure of local governments of Japan and its trends. Basically, this article has been written based on secondary data materials. This data consists of qualitative and quantitative characteristics. Hence, a qualitative and quantitative descriptive method has been applied to analyse the performance of local government decentralization in Japan, and descriptive statistical methods are used to analyse the data and the correlation between revenue and expenditure. The problem in this research is how the functional political institutions created for local service delivery at the sub-national governments in Japan affects the success of decentralization. This research revealed several findings. The local governments of Japan have a sound institutional system and several powers recognized by the constitution. Japanese local governments monitor over $70 \%$ of national works, but a majority of the standard public services are the responsibility of local governments. Karl Pearson's correlation 
value of revenue and expenditure is 0.979 , and there is a strong positive relationship between revenues and expenditure. In Japan, the highest value of local government spending is on public welfare. It is followed by education, civil engineering works, and general administration, second, third, and fourth, respectively. Also, its central and local administrative institutions are maintained in a mutually dependent and mutually complementary relationship. Most of the local governments are collaborating with the private sector in Japan. As a result, the efficiency of service delivery has improved at the local level. In this way, waste management, which is a major local problem in Japan, is being dealt with closely by the central government and the local governments.

Keywords: Decentralization, Service Delivery, Local Autonomy and Developed Countries

\section{Introduction}

Japan consists of the main islands of Hokkaido, Honshu, Shikoku, Kyushu, and Okinawa, and over 6,800 smaller islands of various sizes. Its surface area totals approximately 378,000 square kilometres (Statistical Handbook of Japan, 2019, p. 2). Japan is a unitary state with a constitution that defines the basic organizational structure of governments and the role of authorities. Japanese constitution came into being after World War II. The article 92 and 93 of chapter 8 has guaranteed local autonomy. According to constitutional law, Japan's local government system consists of two levels. The country is divided into 47 prefectures, which are then divided into smaller, and more fundamental local bodies, such as cities, towns, and villages. The major components of the three local government bodies in Japan are as follows: First, local governments play a vital role in the Japanese economy, and the local government expenditure accounts for a fair share of the GDP. Secondly, the local government system is unified throughout Japan, and third, the role of local governments overlaps with the central government and perhaps shows ambiguous aspects concerning their territory (Yagi, 2004, p. 5). Japan is the tenth-largest population in the World, which is 127 million. The Japanese make up $98.5 \%$ of the total population of Japan. The country has a broad industrial capacity and most extensive and most technologically advanced products of the motor vehicles, electronics, machine tools, steel and nonferrous, ships, chemicals, cloth, and processed foods the largest and highest technology products. This development in Japan is due to its political and administrative functional mechanism. Japan has had a long history of local governments and the collapse of the Edo-Shogunate since 1868, the subsequent development of Meiji restoration and the evolution of local government with the 1999 comprehensive decentralization act (Uddin, 2013, p. 937). The local government system in Japan has facilitated a broad-based development of the country. It has been a useful tool for achieving national goals. On the other hand, local governments play a significant role as a vehicle for solving most of the local level problems in Japan (Iqbal, 2001, p. 1). Japan, 
as a developed country in Asia, has given a vital role for local government in the functional political body of the country.

Comparisons have been made with sub-national governments in other developed countries to understand the situation of sub-national governments in Japan. According to Chart 1, data from several developed countries show that sub-national governments' revenues and GDP are doing well. In terms of sub-national revenue and GDP of most developed countries, as per Chart 1, Germany ranks first, Korea second, and Japan third.

Chart 2 shows the expenditure and GDP status of sub-national governments in selected developed countries. Accordingly, Sweden is in the first place by GDP and expenditure. Korea is in third place in terms of GDP, and it is in second place in terms of expenditure. Also, Japan ranks second in terms of GDP, and third in terms of expenditure.

Chart: 1, Sub-national Government Revenue in Selected Developed Countries (US\$ \%)

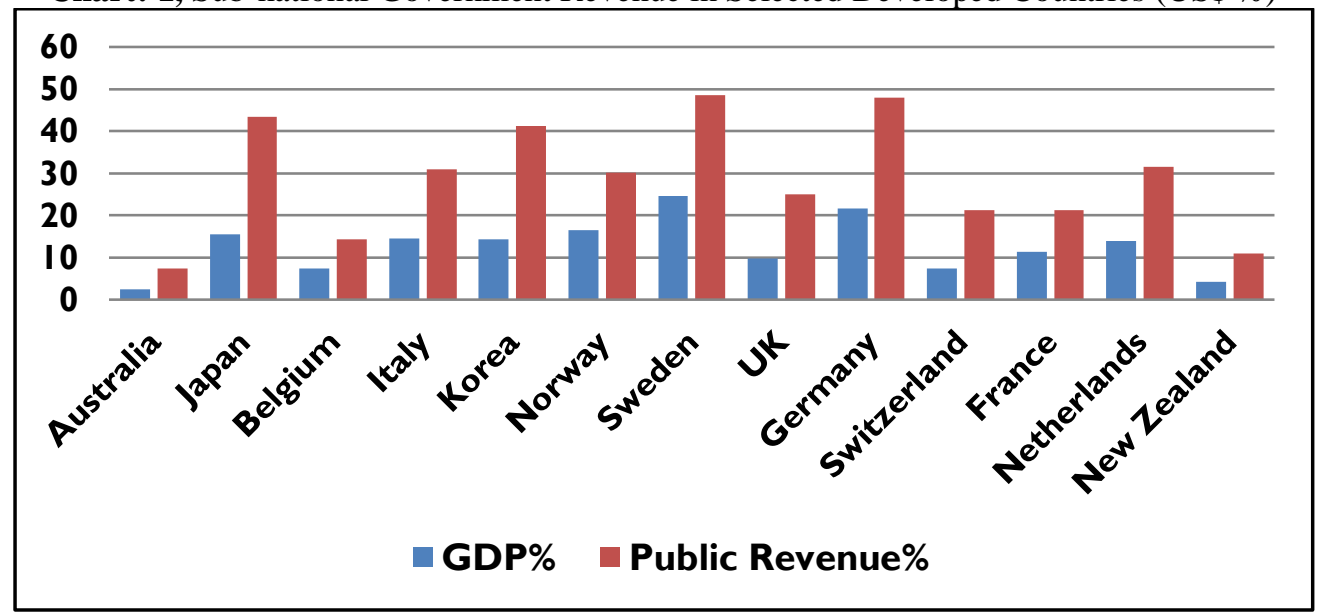

Source:(OECD, 2018)

The rest of this article is organized under several sub-sections as follows: The second section of the report presents the research objectives and methodology with ethnographic and sociological information on Japan. Section three contains a brief literature review based on theoretical and practical evidence, whereas section four covers the descriptive and rational explanation of the government service delivery's sub-national level based on the composition and role of the local governments with the research findings. The final section presents the conclusion. 
Chart: 2, Sub-national Government Expenditure in Selected Developed Countries (US\$\%)

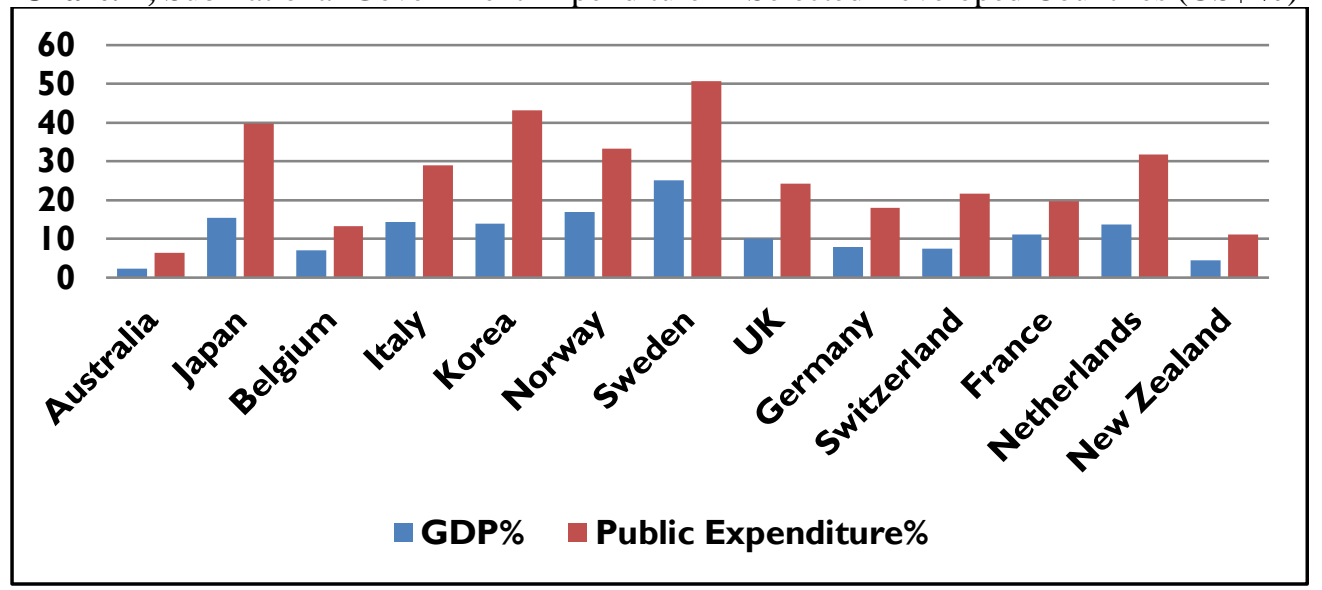

Source: (OECD, 2018)

\section{Research Objectives}

The overall objective of this article is to review the performance of decentralized local service delivery in developed countries, based on a case study of Japan. It also focuses on assessing the importance of the formal mechanism for local governments to provide services and the extent to which the people are involved in their decision-making processes at the local level. Besides, essential issues to consider are identifying the impact of local governments on financial governance and service delivery. In this regard, the article examines the correlation between the revenue and expenditure of local government institutions in Japan.

\section{Research Methodology}

It is particularly important to examine the performance of decentralized local service delivery in developed countries. In this context, this research is focused on the case study of Japan. On the other hand, it can get the same experience for mechanisms in countries with other decentralization systems. This research paper is written based on secondary data materials. These secondary sources of data consist of published and unpublished sources, including case studies, government statistics reports (Statistical Handbooks and Statistical Yearbooks of Japan), books, journal articles, research reports, working paper, the internet browsing sources, and OECD country reports. The data involves qualitative and quantitative characteristics. Hence, a qualitative and quantitative descriptive method has been applied to analyse the performance of local government decentralization in Japan. Accordingly, descriptive statistical methods helped to analyse the data. The correlation between revenue and expenditure, in particular, was tested by SPSS software and Excel. 


\section{Literature Review on Concept of Decentralization}

The literal meaning of the word 'decentralization' in the Latin roots is "away from the centre" (Meenakshisundaram, 1994). There is no single definition of decentralization, but Rondinelli provided a clear description of decentralization as follows: "Decentralisation is defined here as the transfer or delegation of legal and political authority to plan, make decisions, and manage public functions from the central government and its agencies to field organizations of those agencies, subordinate units of government, semiautonomous public corporations, area-wide or regional development authorities, functional authorities, autonomous local governments, or nongovernmental organizations"(Rondinelli, 1981, p. 137). This definition further explains the centre-periphery relations in the state. According to these definitions, various scholars of public administration have defined decentralization as the transference of authority from a higher level of government to a lower level (Herath, 2009, p. 159). Various scholars have defined the concept of decentralization as a transfer of power from a higher level of government to lower level institutions. Accordingly, transferring decision-making power to the delegation, delegating authority power with responsibility, allowing the people to take necessary actions from their placement, distributing tasks from the centre to the periphery, plan formulation, and implementation them with the participation of the people (Hossain, 2005, p. 2).

Many scholars, including the World Bank, point out different types of decentralization. It is useful to understand the theory and practice of this concept, but the concept of decentralization overlaps considerably. Political, administrative, fiscal, and market and asymmetric decentralization can appear in many forms and combinations of countries, countries, and even sectors (Rondinelli, 1999). However, there is no common belief among scholars about decentralization forms. According to Meenakshisundaram, deconcentration, devolution, delegation, privatization, and deregulation are in this way (Meenakshisundaram, 1994, p. 11). Dennis A. Rondinelli and G. Shabbir Cheema have identified four primary forms of decentralization as deconcentration, delegation to semi-autonomous or parastatal agencies, devolution to local governments, and transfer of functions from the public to non-governmental institutions (Cheema \& Rondinelli, 1983, p. 18). Edward Mugabi showed that decentralization could be divided into four types. This includes deconcentration, devolution, delegation, and divestment/privatization (Mugabi, 2005, p. 24). This proves the different views about the forms of decentralization.

Various scholars who have discussed the concept of decentralization categorize it into two waves, called as the first wave of decentralization and the second wave of decentralization. The first wave of decentralization or the 
first generation of decentralization is based on the period from the late 1960s to the mid-1970s in many parts of the Asian and African regions (S. Chowdhury, 2017, p. 116). However, as Olsen points out, the first-generation decentralization failed due to several reasons. These include lack of people participation, lack of local administrative performance and capacity, and the distribution of power, wealth, and status has not changed. However, by the beginning of the 1990s, many developing countries were using the second wave or second-generation decentralization. The second generation of decentralization moved from reform to restructuring to shift the decisionmaking process from the centre to the periphery (Olsen, 2007, pp. 2-3). They pointed out that the second wave, or second-generation decentralization, can be observed in four categories, as political, administrative, fiscal, and market decentralization (S. Chowdhury, 2017, p. 117).

Many governments in the world use decentralization under different layers for various political, administrative, and economic purposes. Cheema and Rondinelli (1983, pp. 14-16) produced the best summary of those purposes: "Increase people's participation in local development, planning, and management, coordinate administrative functions, political and administrative "penetration", creating social equity, more effective coordination, allowing local "experiments", lead to more flexible, innovative and creative administration, isolated or backward areas of development, integration of regional economies, macroeconomic stability, improve political stability, decentralizing public goods and services, participation planning, monitoring, and evaluation, delivery of goods and services, local-level financial management and administrative efficiency, so on" (Mudalige, 2019, p. 120). In addition, Olsen $(2007$, p. 3 ) pointed out that the second wave, or secondgeneration decentralization reform, is aimed at state reform (state modernization), local governance, local democracy, and regional economic development. Thus, the countries in the world aim to solve many complex social, economic, and political issues related to governance through decentralization reforms.

According to Piccone, 2.28 billion people lived in democratic countries in 1989 , which increased to 4.18 billion by 2014 . The democratization of countries also leads to more decentralization. In 1989, there were 69 democratic countries, which rose to 125 by 2014 (Piccone, 2016, p. 2). Further, some countries have implemented decentralization systems for improving the governance mechanism within the state. Different types of decentralization methods are identified according to Table 1, as the political, administrative, fiscal, market, and asymmetrical decentralization. These decentralization methods have appeared in various countries and used as many combinations (Islam \& Fujita, 2012, p. 5). Also, as mentioned above, it is vital to have an overview of the five types of decentralization. 
Table: 1, Various Types of Decentralization

\begin{tabular}{|c|l|l|l|l|}
\hline $\begin{array}{c}\text { Forms and } \\
\text { Dimensions }\end{array}$ & Privatisation & Delegation & Deconcentration & Devolution \\
\hline Market/Economic & & & & \\
\hline Administrative & & & & \\
\hline Political & & & & \\
\hline Fiscal & & & & \\
\hline Asymmetric & & & & \\
\hline
\end{tabular}

Sources: Steiner (2005, p. 10), Muriu (2013, p. 7), and Hossain (2005, p. 6)

Political Decentralization: The purpose of political decentralization is to empower citizens or their elected representatives to make public decisions at the sub-national level in the central government. John Mary Kauzya has given a more explicit definition for understanding political decentralization: Political Decentralization is "transferring the power of selecting political leadership and representatives from central governments to local governments, and transferring the power and authority for making sociopolitico-economic decisions from central governments to local governments and communities" (Kauzya, 2007, p. 76). Thus, political decentralization means delegating authority to the sub-national body by the central government. Political decentralization can be identified as the most popular and most democratic system of decentralization. The method of devolution of power is carried out under political decentralization.

Administrative Decentralization: In general terms, the process of transferring central government structures and bureaucrats to the local level involves administrative decentralization. As defined by Rondinelli, "Administrative decentralization seeks to redistribute authority, responsibility, and financial resources for providing public services among different levels of government" (Rondinelli, 1999, p. 2). Administrative decentralization aims to redistribute authority, responsibility, and funds among different levels of government services. Administrative decentralization is often associated with civil service reform in a country. Similarly, decentralization models such as deconcentration and delegation are implemented under administrative decentralization.

Fiscal Decentralization: As per Work's definition, "Fiscal decentralisation means the reallocation of resources to the sub-national levels in a government." Arrangements on the resource allocation are often negotiated between the central and local government authorities based on various factors including interregional equity, availability of resources at all levels of government, and local fiscal management capacity (Work, 2002, p. 6). Sub-national governments have now become key actors of public goods and services to citizens of countries around the world. Therefore, it is 
increasingly important to know the impact of fiscal decentralization on the economy, society, and politics. A wide range of socio-economic issues includes growth and development, poverty reduction and achieving the Millennium Development Goals (MDG), enhancing public sector efficiency and governance, or greater macroeconomic stability and fiscal sustainability (Vazquez, Peñas, \& Sacchi, 2015, p. 1). Under fiscal decentralization, the emphasis is on strengthening sub-national finance capacity. This means that it is essential to give sub-national governments some revenue authority and a spending responsibility. Therefore, these sub-national institutions can determine the level and structure of their budget.

Economic or Market Decentralization: The processes of privatization and deregulation introduced through market decentralization are determined by the nature of economic liberalization and market development policies in countries. In a country, under economic decentralization, the responsibility shifts from the public to the private sector. Economic or market decentralization means transfer over the functions of the government to the private sector. It shows through privatization and deregulation. This kind of decentralization promotes the engagement of businesses, community groups, co-operatives, private volunteer associations, and other non-government organizations (Hossain, 2005, p. 5). In practice, the privatization of state enterprises and the deregulation of markets are relevant to economic or market decentralization.

Asymmetrical Decentralization: The creation of asymmetric decentralization begins when governments of the same sub-national level have different political, administrative, or fiscal powers (OECD, 2019, p. 20). Ronald L. Watts points out that asymmetric decentralization can be categorized into two methods: The first one of political asymmetry is seen as arising "from the impact of cultural, economic, social, and political conditions affecting the relative power, influences, and relations of different regional units." The second one is an asymmetry, which he labels as constitutional asymmetry, "relates specifically, to the degree to which power assigned to regional units, by the constitution of the federation are not uniform" (Amarasinghe, 2011, p. 145). In general, asymmetric decentralization of unitary states is more likely to occur in practice (Utomo, 2009, p. 19). However, asymmetric decentralization has become more common in the unitary and federal states.

\section{Literature Review on Practices of Decentralization}

This discussion focuses on the practical application of decentralization in countries based on local service delivery. Iritani and Tamaoka (2005) have discussed the Japanese fiscal structure between central and local governments. This study was based on the Japanese fiscal structure. It aims to evaluate the 
inter-fiscal compatibility of the post-war period. This study revealed that problems are present in the entire financial redistribution system between the central and local authorities, which need to be regulated. Ikawa (2008) discussed Japan's fifteen-year decentralization reform. The study highlights the importance of training human resources in the long term of financial management.

Conversely, it is necessary to understand the local citizens to promote decentralization. At the same time, it is essential to involve citizens in the decision-making process of provincial governments. Moreover, the autonomy of the local government finance sector has not been satisfactorily achieved. Kimura (2015) studied the structure of the Japanese local revenue and the framework of the Japanese local tax system and emphasised that local preferences should be allowed to be sensitive when determining the tax rate and basis. Also, local authorities must be more sensitive to the needs of the community within the framework of financial autonomy. Shirai (2004) has studied the local allocation tax concerning local governments in Japan and investigated whether the income gap between prefectures decreased between 1980-2001. Also, this study reviewed the conditions of developing countries and their intergovernmental transfer system. Furthermore, Shirai pointed out that Japanese experience shows a need for careful planning of an intergovernmental transfer system so that it does not pose a moral hazard to the economically poor.

It is also necessary to promote private sector economic activity and regional economic growth. S. Chowdhury (2017) evaluated the process of participatory planning and participatory budgeting through local governments in Bangladesh. The findings revealed the importance of increasing people's participation, increase trust in elected representatives, change patterns of service delivery, and improve the validity of transferring funds directly to local governments. However, local resources constraints and local political interference have negatively impacted the performance of local governments. Thießen (2003) analysed his study of fiscal decentralization from an economic growth perspective. This has been used in per capita economic growth, capital formation, and overall factor productivity growth in high-income OECD countries. This analysis focuses on cross-sectional regressions based on the average of the annual time series data as 1973-98. The researcher found no significant difference in long-run investment performance among countries with low or high fiscal decentralization. Also, countries with low fiscal decentralization tend to have it increased, while countries with higher fiscal decentralization tend to have it decreased. Lin and Liu (2000) investigated the impact of fiscal decentralization on China's economic growth, widely using the empirical literature in this study. 
A production-function-based regression analysis framework has been used for this research. The researcher used provincial-level panel data set from the 1970s to 1993. The findings of this research show that fiscal decentralization has positively contributed to economic growth. Bessho (2006) conducted a case study on the financial performance of Japan's central government and local governments. The purpose of this paper is to provide a preliminary analysis of the local public administration and functioning of the financial system of local governments, and, besides, it aims to analyse the financial balance in the aftermath of a fiscal shock in Japan. Based on quantitative data, the VECM approach has been employed for data analysis in this research. The study reveals that local governments can cover a $40 \%$ increase in their own source of income through a reduction in grants. Kimura (2017) examined the Japanese local revenue tax and its financial autonomy goals. The author points out several problems with the Japanese local tax system. They are to reduce the disparity in the local tax system, enrich the financial autonomy, and stabilize tax revenues. Also, he noted that the local governments should be more sensitive to the community needs within the framework of financial autonomy.

Davoodi and Zou (1988) investigated the relationship between fiscal decentralization and economic growth. In this research, a panel dataset of 46 countries was used for the period 1970-1989. The research findings indicate a negative relationship between fiscal decentralization and economic growth in developing countries. Woller and Phillips (1998) have presented an empirical investigation of the relationship between fiscal decentralization levels and economic growth rates based on across a sample of 23 less developed countries for the years 1974 through 1991. It agreed with Davoodi and Zou's view and disclosed a weak inverse relationship between economic growth rates and level of fiscal decentralization. Barrett (2000) has discussed the steps to promote decentralization in Japan and its results. The study points out the challenges to overcome many political, social, institutional, administrative, and financial obstacles to implement decentralization in Japan successfully.

Japan's local authorities do not have greater financial independence. As a result, localisation is no longer implemented as a target. Szabo (2017) examined the empirical relationship between fiscal decentralization and economic growth. It can be noted that he has used the research for an in-depth analysis of the independent and control variables used in the regression. He analysed over 30 variables that can be used in fiscal decentralization and over 60 control variables with an impact on economic growth. This study provides a significant literature background for qualitative data analysis.

Rahim and Shirazi (2018) have investigated citizens' satisfaction with the delivery of government services through local government in Pakistan. In this study, multiple-choice models have been used to identify citizen 
satisfaction with service delivery. This research disclosed the devolution policy variables are statistically significant. The demographic and socioeconomic variables have also become important. It is revealed that devolution is heading in the right direction when it comes to reducing income disparities. Zhao (2009) has examined Chinese state-level fiscal disparities using financial and economic data for the period 1978 to 2016 and realised that some of China's primary education, public health, and welfare services had not been provided with decentralization, and fiscal disparities compound these problems.

Lewis, Mcculloch, and Sacks (2016) have investigated the measurement of service delivery of provincial governments in Indonesia. The study highlighted the importance of considering the reliability and validity of the indicators used. This study also provides some important indicators of education and health. The literature review demonstrated that in many countries of the world, the responsibilities of governance had been placed on the periphery. It has been implemented under the local government layer system. The introduction of local government layers is intended to make services at the local level more efficient.

\section{Local Governments of Japan}

The Japanese government system consists of three layers as the central government, prefectural governments, and municipal governments. There are 47 prefectural governments as the second layer. They are consisted of "to" (Tokyo), "do" (Hokkai), "fu" (Osaka and Kyoto), and 43 "ken." The prefectures of "Do," "Fu" and "Ken" are assigned the same functions. However, for special reasons, "to" has been assigned special functions. Tokyo is the capital city of Japan, with a large population in a small area-hence, Tokyo has been given a special status. The third layer is divided into Cities ("Shi"), Special wards ("Ku"), Towns ("Machi" or "Cho"), and Villages ("Son" or "Mura") (see figure 1). They operate from urban, rural, and regional institutions (Bessho, 2006, p. 5);(Yagi, 2004, p. 8). However, as of 1 January 2019, Japan has 47 prefectures and 1,718 municipalities Japan (CLAIR, 2019b, p. 7; Statistical Handbook of Japan, 2019, p. 194). Scholars commenting on the local government have recognized that the "local government is an umbrella term." In particular, considering this idea, a local government can mean country, a municipality, a city, a town, a township, a local public authority, a school district, a regional or interstate government entitles, or any agency or instrumentality of a local government (European Commission, 2007, p. 19). Thus, it is correct to recognize the prefectural government and municipalities of Japan as local governments.

The governor of a prefecture or the mayor of a municipality is the most influential chief executive of the local government in Japan. These top 
executive representatives represent the local government and are directly elected by the people, and the term of office of the elected executive representatives is four years. These executive representatives are empowered to ensure the overall compliance of all government operations. In addition to that, they have the power to act as government representatives to the outside world. The executives have the authority to enact necessary regulations, make budgets, propose bills, and appoint or dismiss staff members. In addition to the governors and mayors in local governments, deputy governors or deputy mayors have been appointed to carry out their duties (Michihiro, 2010, pp. 1112). The organizational structure of the prefectures and municipalities are shown in the Annexe, in 1 and 2, respectively. The executive bodies of local governments in Japan include boards of education, electoral administration commissions, personnel commissions, as well as prefectural governors or municipal mayors. The deputy Governors and deputy Mayors are appointed by the governors and mayors of local Governments with the consent of the legislative assemblies (Sasaki, 2014).

Figure: 1; Japanese Government Institutions by Level

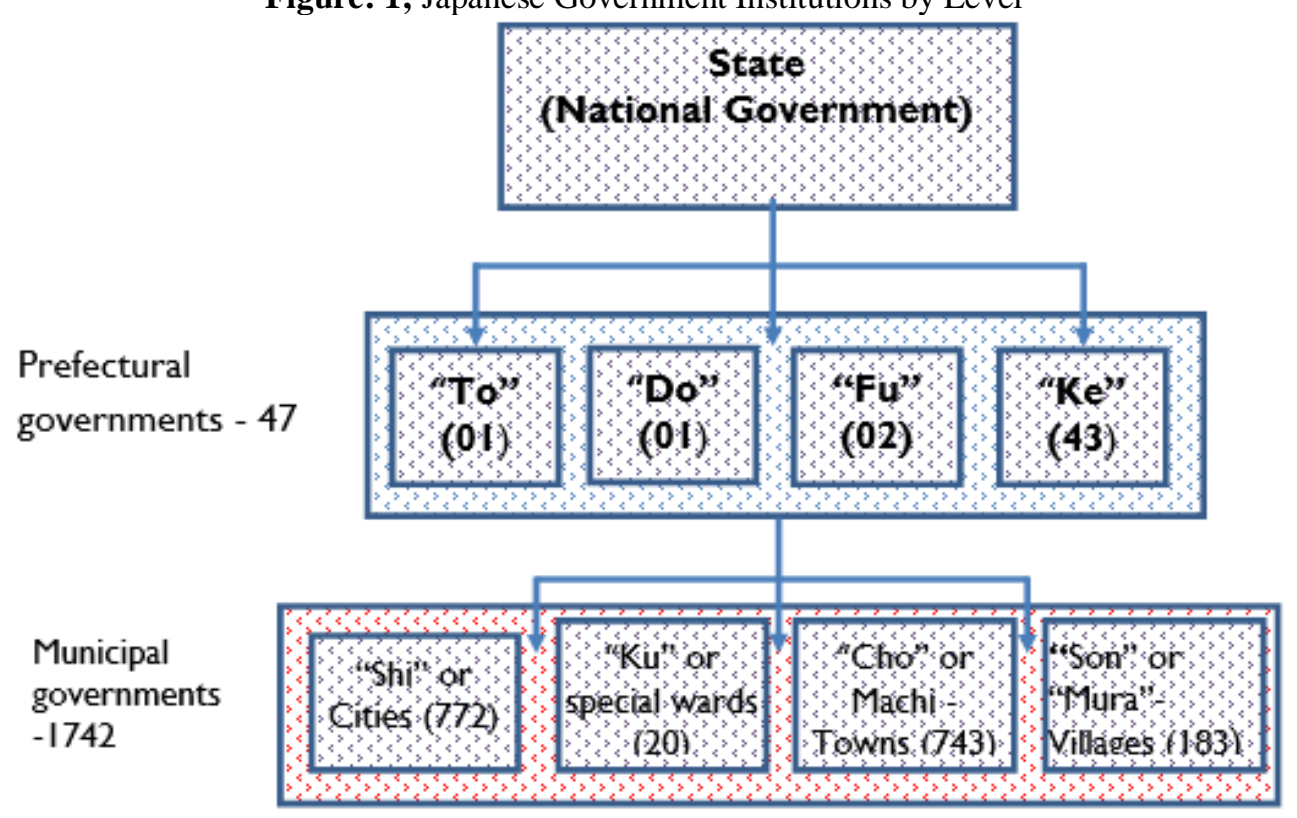

Source: (Statistical Handbook of Japan, 2019, p. 194) and (UNCRD, 2014, p. 4)

Japan has many responsibilities to serve the people through local government. Thus, the local governments in Japan can identify some of the responsibilities and strategies used to meet their responsibilities. Accordingly, it is empowered to use a variety of tactics to perform its responsibilities. These facts are explained under several themes. 


\section{Discussion}

Local Service Delivery: Local Services delivery has become an essential part of the relationship between government institutions and citizens. Also, local service delivery cannot be taken as an isolated matter, and it appears to be part of a complex relationship between government, society, and citizens. In general, citizen satisfaction, trust, credibility, and legitimacy must be ensured in government-led service delivery. Trust is a crucial element of the relationship between voters and their elected representatives, as well as part of the political system. Furthermore, the local service delivery is the determinants of the government's image, the position of the government, and the legal basis of its work (Eigeman, 2007, pp. 8-10). The European Commission has highlighted some advantages of local service delivery, such as more adequate to local needs, more flexible, more innovative, cheaper, sustainable, mobilizing the comparative advantages of local enterprises and the local non-profit sector, mobilizing local resources through taxation, and downward accountability (Olsen, 2007, p. 14).

According to Figure 2, considering the type of administrative services in Japan, the majority of local government employees applies to the field of providing education services. The general administrative services hold the second position while social welfare and public hygiene represent the third. Police service is the fourth important sector. It also identifies that a significant proportion of employees represents hospitals, fire services, water and sewerage, and transportation in the country.

Japanese local governments monitor over $70 \%$ of national works, but a majority of the standard public services are the responsibility of local governments. Local governments in Japan have a substantial role to play in fulfilling people's needs. Regarding broad responsibilities, prefectural roads, disaster restoration, harbours, agriculture, forestry, fisheries and river conservancy, public health affairs, vocational training, and police are prominent. They also include communication and coordination affairs, high schools, museums, hospitals affairs, commerce and industry, affairs relating to the fundamentals of residents' lives, fire service, garbage disposal, water supply, sewage, debt service, the welfare of residents, urban development, public halls, citizens' halls, day-care facilities, elementary and junior high schools, and libraries. Also, the above performances of prefectures and cities have been delegated to local governments (Ikawa, 2008). Local governments are implementing large administrative tasks that are locally important. 
Figure: 2, Local Government Employees by Type of Administrative Services in Japan

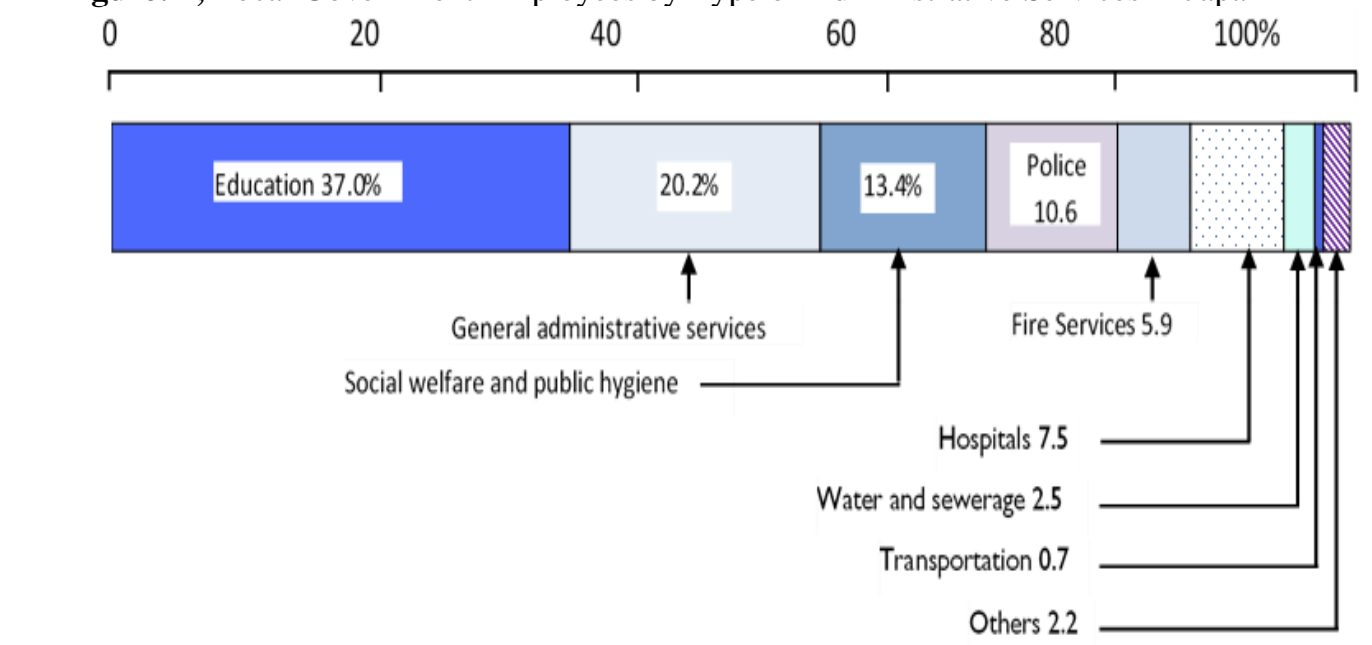

Source: (Statistical Handbook of Japan, 2019, p. 195)

Local Governments Finance: In Japan, the local financial system (trinity reform) is restored with the objective of promoting local administration. It has three main goals: (1) Reduction of treasury disbursement, (2) Reduction of local allocation tax, and (3) Tax sources transfer from the central government to local government. Its objectives are (a) strengthening the autonomy in the local society and (b) reforming the public finance and administration in Japan as a whole (Kayama, 2007, p. 1). Local government revenue in Japan is compounded by several key themes. They are general revenue resources, local taxes, local transfer tax, special local grants, local allocation tax, national treasury disbursements, bonds for the extraordinary financial measures, local bonds, and other revenue resources (Kimura, 2015, p. 92). As per Table 2, Japan's local governments report higher revenue than expenditure. It contributes to the strength and autonomy of the local governments, as evidenced by the data from 2009 to 2017. A large portion of the local governments' expenses is directly related to the daily lives of the Japanese people. Several essential sources of such expenditure can be pointed out as, sanitation expenses such as medical services and garbage disposal; school education expenses; judicial, police, and fire service expenses; and welfare expenses that cover the development and management of welfare facilities for children, the elderly, and mentally- and/or physicallychallenged (Statistical Handbook of Japan, 2019, p. 39). 
Chart: 3, Relationship between Revenues and Expenditures Local Governments in Japan

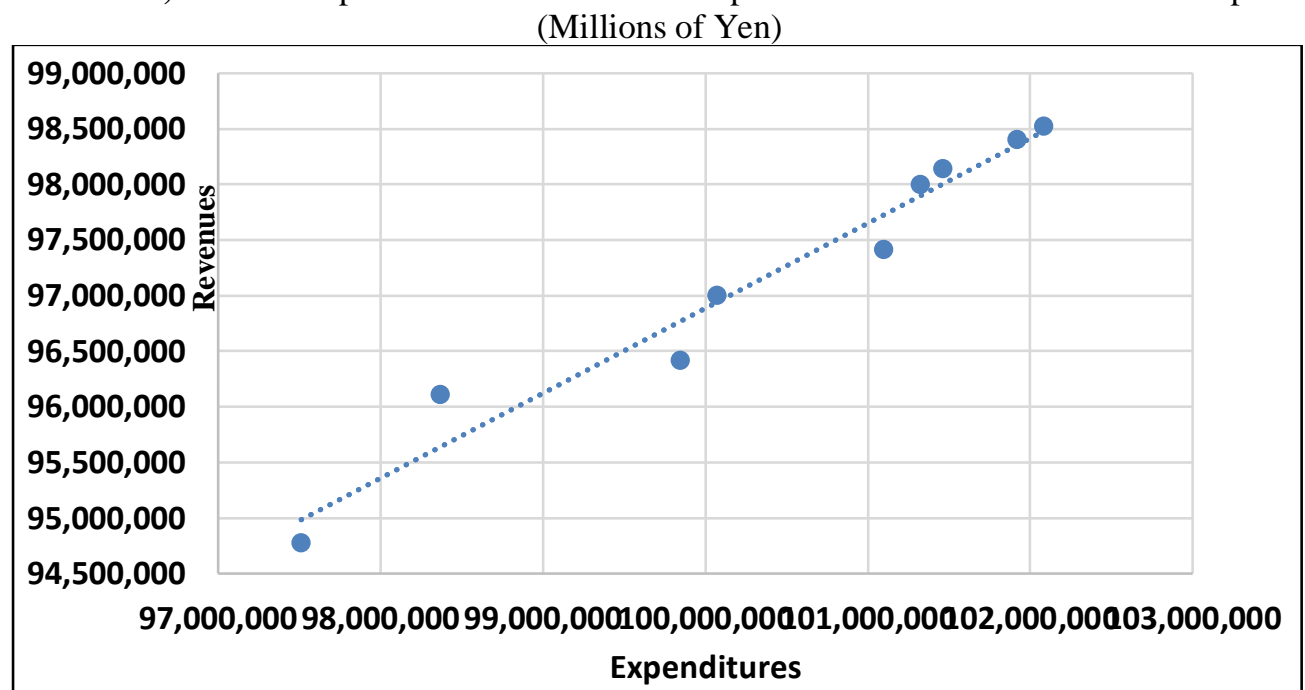

Source: (Author's calculations, 2020)

The scatterplot in Chart 3 shows a linear relationship between revenues and expenditure of the local government in Japan

Table: 2, Correlations

\begin{tabular}{cccc}
\hline \multirow{3}{*}{ Revenues } & & Revenues & Expenditures \\
& Pearson Correlation & 1 & $.979^{* *}$ \\
& Sig. (2-tailed) & & .000 \\
\cline { 2 - 4 } Expenditures & $\mathrm{N}$ & 9 & 9 \\
& Pearson Correlation & $.979^{* *}$ & 1 \\
& Sig. (2-tailed) & .000 & \\
& $\mathrm{~N}$ & 9 & 9 \\
\hline
\end{tabular}

Source: (Author's calculations, 2020)

According to Table 2, Karl Pearson's correlation value of revenue and expenditure is 0.979 , and its $\mathrm{P}$-value is 0.000 . Hence, there is a strong positive correlation between Revenues and Expenditure. Creating two hypotheses is necessary when calculating this.

$\mathrm{H}_{0}$ : There is no significant relationship between Revenues and Expenditure.

$\mathrm{H}_{1}$ : There is a significant relationship between Revenues and Expenditure.

Also, in the above calculation, the $\mathrm{p}$-value is less than 0.05 . Hence, with $95 \%$ confidence, it can be concluded that there is a significant relationship between Revenues and Expenditure. 
Table: 3, Descriptive Statistics on the Revenue and Expenditure of the Local Governments

\begin{tabular}{|c|c|c|c|c|}
\hline & Minimum & Maximum & Mean & Std. Deviation \\
\hline Revenues & 97511501 & 102083467 & 100408187.22 & 1600903.921 \\
\hline $\begin{array}{c}\text { General } \\
\text { administration } \\
\text { (Expenditure) }\end{array}$ & 8901591 & 10718365 & 9725424.67 & 549333.867 \\
\hline $\begin{array}{l}\text { Public welfare } \\
\text { (Expenditure) }\end{array}$ & 19767874 & 26340756 & 23656917.11 & 2148233.968 \\
\hline $\begin{array}{c}\text { Sanitation } \\
\text { (Expenditure) }\end{array}$ & 5812417 & 6743245 & 6163903.11 & 272527.170 \\
\hline $\begin{array}{l}\text { Agriculture, } \\
\text { forestry \& fishery } \\
\text { (Expenditure) }\end{array}$ & 3171208 & 3552987 & 3302867.78 & 139431.352 \\
\hline $\begin{array}{l}\text { Commerce and } \\
\text { industry } \\
\text { (Expenditure) }\end{array}$ & 4901049 & 6575008 & 5862836.22 & 612388.418 \\
\hline $\begin{array}{l}\text { Civil engineering } \\
\text { work (Expenditure) }\end{array}$ & 11242282 & 13292043 & 11955439.00 & 596815.982 \\
\hline $\begin{array}{c}\text { Education } \\
\text { (Expenditure) }\end{array}$ & 16087778 & 16888597 & 16487264.22 & 301525.306 \\
\hline
\end{tabular}

Source: (Author's calculations, 2020)

Table 3 shows the mean value of revenue and expenditure of local governments in Japan from 2009 to 2017. Also, the highest mean of expenditure was recorded for public welfare, which was 23656917.11. Furthermore, the mean of education expenditure came in second with 16487264.22. The lowest expenditure mean value is agriculture, forestry, and fishery, which is 3302867.78. As chart 4 shows, the period from 2009 to 2017 shows an increase in revenue over the expenditure of local governments of Japan.

Chart: 4, Local Governments' Finance Capacity in Japan - 2009-2017

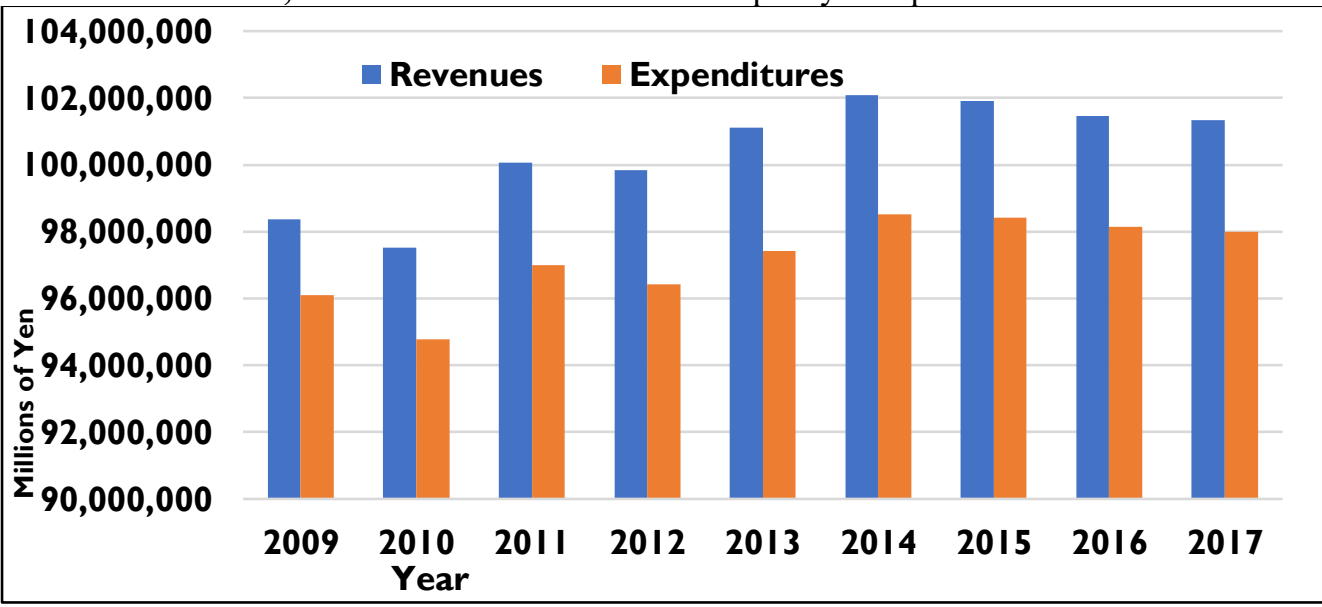

Source: (Japan Statistical Hand Books, 2009-2019) 
Chart 5 shows the shape of revenue in Japan's local governments in 2016 and 2017. The largest share of local governments' fiscal 2017 (net) revenue came from local taxes, which accounted for 39.4 per cent of the total, and the second-largest source, 16.5 per cent, for local allocation tax. Similarly, the large portion of fiscal 2016 (net) revenue came from 38.82 local taxes and secondly the local allocation tax of 16.99. In addition to local taxes, the local allocation tax is also necessary, and it has contributed to increasing the financial capacity of local governments. Local allocation tax grants are the general objectives disbursed through the central government special account. According to the Ministry of internal affairs and communications, the goals of the local allocation grant are to adjust imbalances in tax revenue inconsistencies between local governments and guaranteed revenue sources. In Japan, local governments have a higher level of authoritative power to operate independent financial operations and access resources (Uddin, 2013, p. 940).

As per Chart 6, in Japan, the highest value of local government spending is on public welfare. It is followed by education, civil engineering works, and general administration, second, third, and fourth, respectively. Also, the lowest expenditure was reported on agriculture, forestry, and fishery.

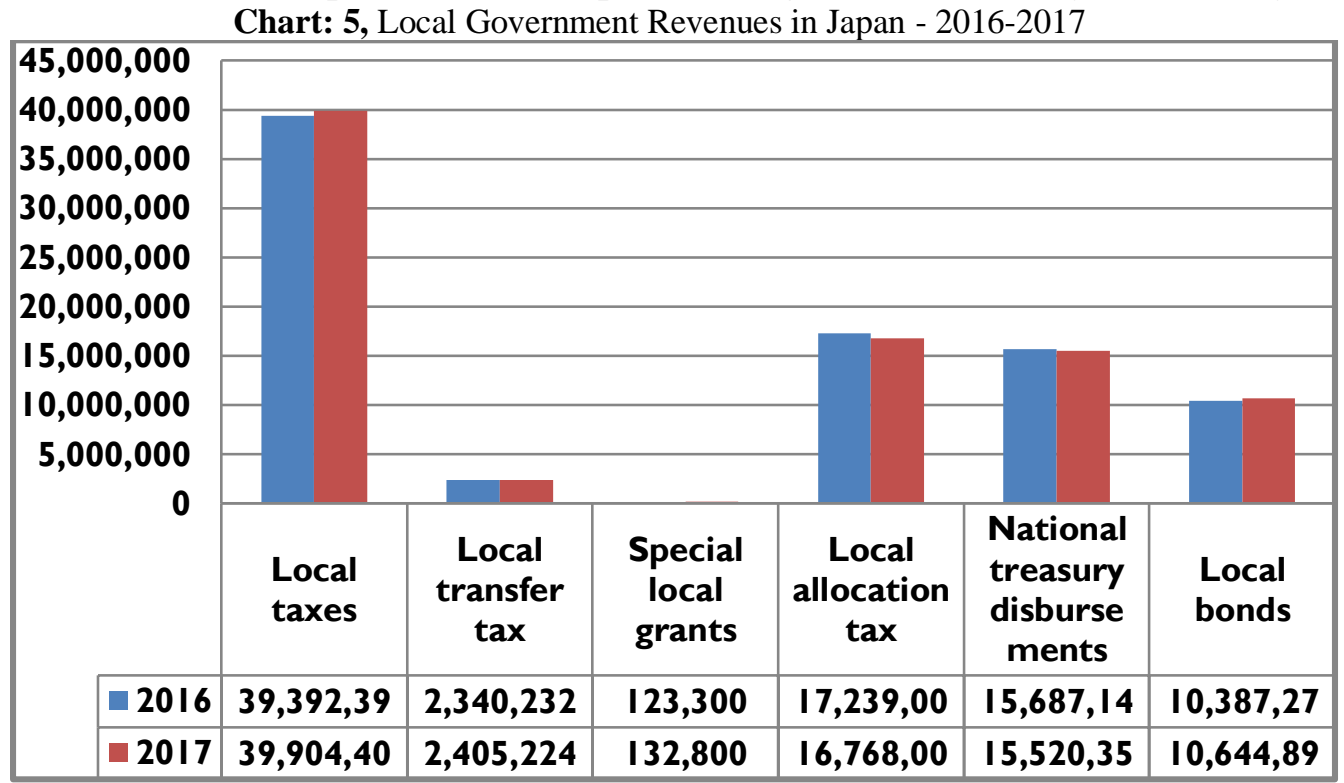

Source: (Statistical Handbook of Japan, 2019, p. 39) 
Chart: 6, Expenditure on Subjects of Local Governments in Japan

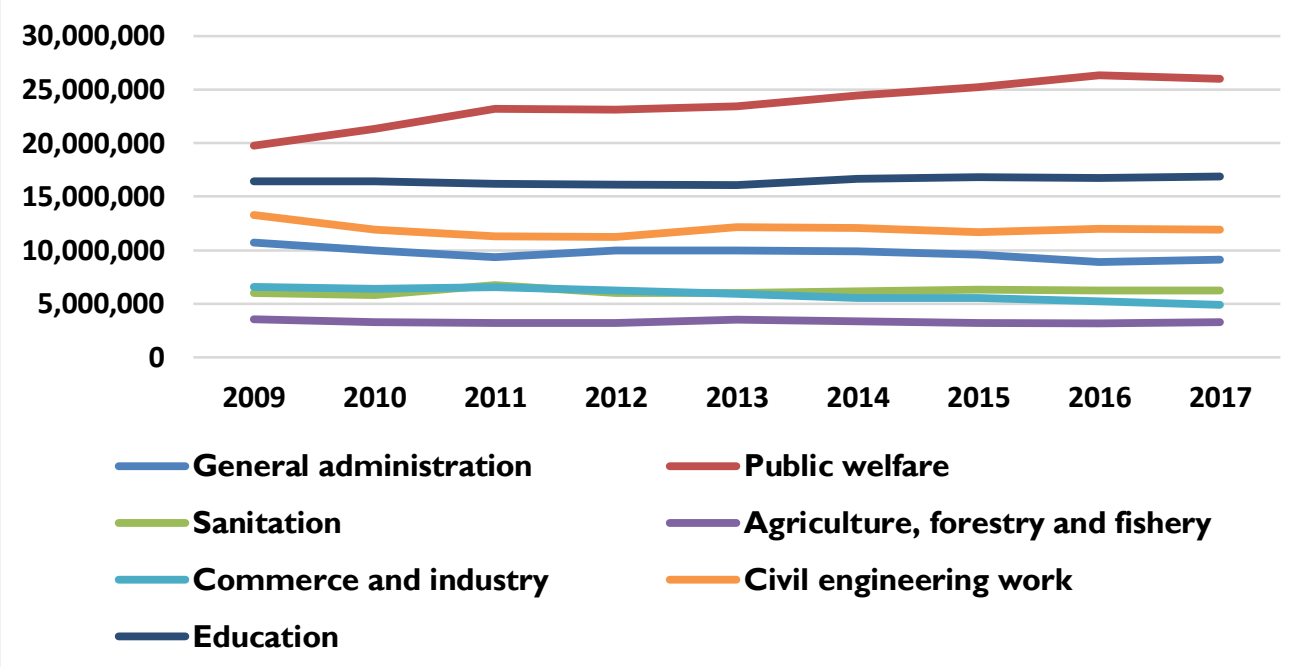

Source: (Statistical Handbooks of Japan, 2018, 2019).

Local Autonomy: A special feature of Japan's local governments is the recognition of "local autonomy" by the constitution. Articles 92, 93, 94, and 95 contained in Chapter VIII of the Constitution provide for the "local autonomy" of the local government. In addition to local Autonomy Law concerning local governments, various laws have been enacted such as the Local Public Service Law, the Public Offices Election Law, the Local Finance Law, and the Local Tax Law (CLAIR, 2019a, p. 2). The Local Autonomy Law 1947 describes the types of local authorities, residents, powers, responsibilities, and functions of organizations and the central-local relationship (M. S. Chowdhury \& Hossienie, 2012, p. 25). Through the democratization program introduced in Japan in the late 20th century, local governments were able to gain local autonomy, allowing them to manage public policy aspects in areas such as regional development, welfare, environmental development, and government information disclosure. As a result, Japanese local governments have increasingly become active actors in the policymaking process (Patwar, 2014, p. 23).

Number of Administrative Layers: In general, prefectures and municipalities' Local Autonomy Law is defined as the two basic types of local government, while Japan's local autonomy system follows a two-tier prefecture system as regional government units and municipalities as basic local government units. Also, creating local governments in Japan has made it easier to provide services, taking into account the geographical conditions, the size of the population, the content of regional administrative services, and the degree of centralization of power (CLAIR, 2019a, p. 2). Figure 2 above shows the layers of local government in Japan. In Japan, local governments have 
been established as part of the system of governance for the entire nation. Also, its central and local administrative institutions maintain a mutually dependent and mutually complementary relationship (Patwar, 2014, p. 26).

\section{Central and Local Relation}

There is a clear line of division of functions and responsibilities among the central, prefectural, and municipal governments in Japan. As such, there is no room for the central government to intervene in the local governments' activities. Moreover, local governments provide many services close to the daily lives of people. Therefore, the central government can focus on issues with national importance and other domestic needs of the country.

Japan's central government is always in the process of protecting local governments. Also, the local government prepares its own budget and the central government finances it with its own "local allocation tax" to ensure that the local people get a proper service (M. S. Chowdhury \& Hossienie, 2012, pp. 32-33). "The local allocation tax grant" means an unconditional grant of the central government to local governments. The local allocation tax law outlines two main functions through "the local allocation tax grant." They are (1) equalization of local government fiscal capacity to compensate for regional disparities in fiscal sources, and (2) revenue guarantees for local governments to provide public goods and services. The central government assists the local government to overcome the revenue shortfall through the local allocation tax grant, thus enabling the local governments to manage its responsibilities (Aoki, 2008, p. 29).

Chart 7 illustrates the local allocation of tax to the local government layers by the central government of Japan. Furthermore, it shows that prefectural governments have been given more importance in the local allocation of tax. Local allocation tax grants are the general objectives disbursed through the central government special account. According to the ministry of internal affairs and communications, the objectives of the local allocation grant are to adjust imbalances in tax revenue inconsistencies between local governments and guaranteed revenue sources. Therefore, in some areas, administrative services can be provided with a certain level of administrative services. 
Chart: 7, Grants of local allocation tax by central government - 2005-2016 (Billions of Yen).

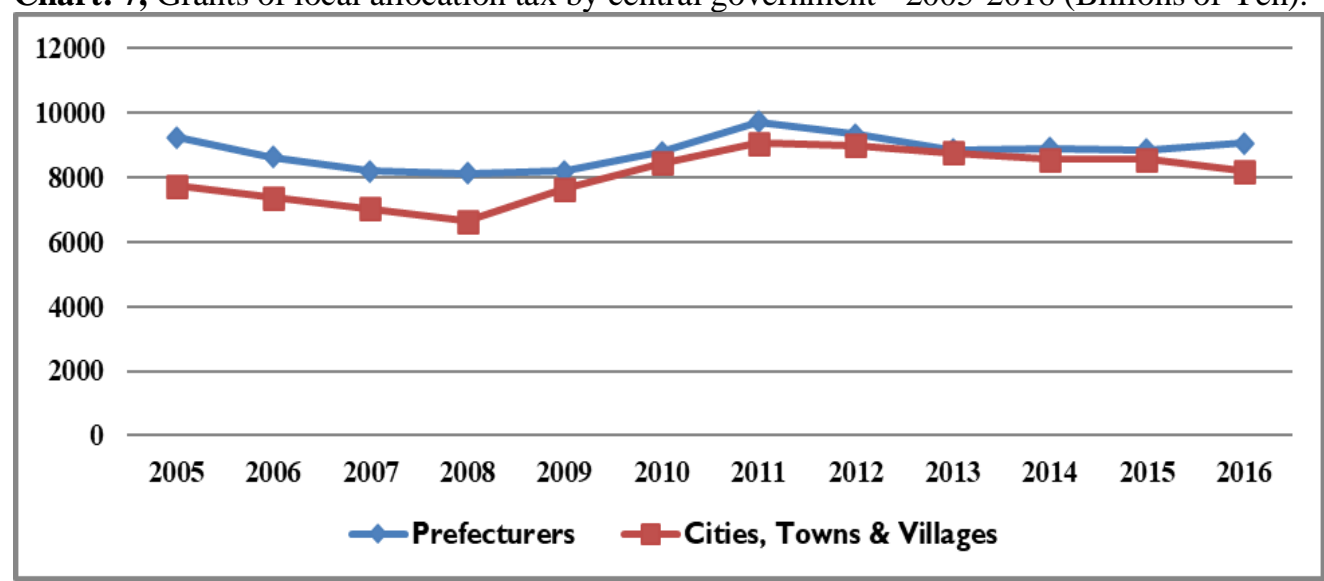

Source: (Japan Statistical Year Books, 2005-2016).

There are two types of treasury disbursements. First one is 'Disbursements of the national government to local governments,' and the second one is 'Disbursements of local governments to the national government.' However, the central government's national treasury disbursements process is discussed here. Japan's central government provides financial assistance for services or programmes offered by the local government through the national treasury disbursements. This could be classified into three: (1) National treasury obligatory share, (2) Central government subsidy, and (3) National treasury payment for agential tasks. The National treasury obligatory share means "the central government bears the whole or a part of the cost of a service or a programme provided or implemented by the central government and a local government under joint responsibility," for example, compulsory education. The central government subsidy means "the central government bears the whole or a part of the cost of a certain service or programme provided or implemented by a local government to encourage or facilitate it," for example, road development. National treasury payment for agential tasks means "the central government bears the whole cost of a service or programme provided or implemented by a local government on its behalf," for example, national census affairs. Nonetheless, unlike local allocation tax grants, the central government specifies the usage of national treasury disbursements (UNCRD, 2014, p. 42) (Aoki, 2008, p. 35). Treasury disbursements have a strong bond between the central government and the local governments. 
Chart: 8, Trend of treasury disbursements (national \& local) in Japan 2008-2019.

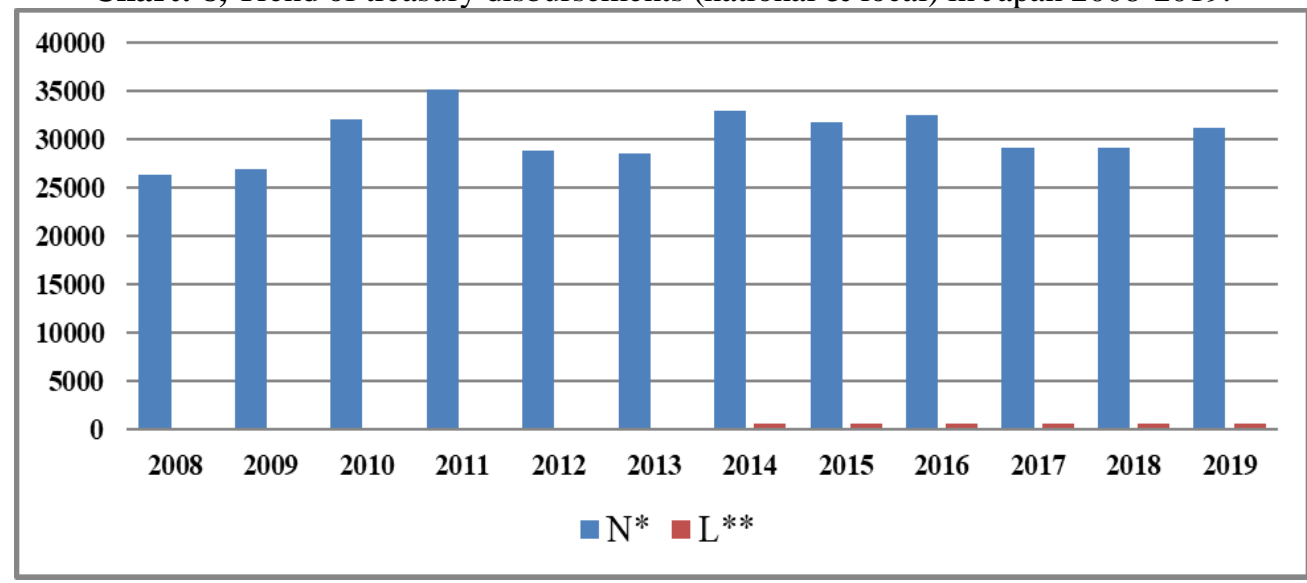

Source: (Japan Statistical Year Books, 2008-2019)

$\mathbf{N}^{*}$ Disbursements of the national government to local governments, $\mathbf{L}^{* *}$ Disbursements of local governments to the national government.

Chart 8 presents Japan's trend of treasury disbursements from 2008 to 2019. The fund has created regional development efforts with the central government, and through this process, Japan's central government maintains a close relationship with local governments.

Local Government Assemblies: Japan's local government assemblies appear to have been formed based on a deep democratic system. These assemblies are deliberate bodies composed of members directly elected by the residents of the area. Similarly, representatives of elected local governments, based on a limited age group, are entitled to vote in their own council. The members submit bills to regulate the provision of services in their area, and they have to be approved by the assembly (CLAIR, 2019a, p. 11). There are many committees in the working of the local governments, some of them the board of education, public safety commission, and board of elections. The legal system and the constitution give a guarantee to the local governments in Japan. As a result, local governments can work independently and formulate and enforce the law within their jurisdiction (Patwar, 2014, p. 25).

Legislative Process of Local Governments: Local governments are empowered to enact "local ordinances" according to their requirements to strengthen Japan's local service delivery mechanism. Accordingly,

"Local public entities shall have the right to manage their property, affairs, and administration and to enact their own regulations within law-Article 94, Constitution."

By allowing it, provincial governments can enact two types of laws such as 'local ordinances' and 'regulations.' 
Japan's local government structure provides a check and balance system that controls each other's activities, such as executive and legislative bodies. As a result, there is no room for any branch of local government to misuse power (Patwar, 2014, p. 25).

Residents' Rights and Roles: The local autonomy system of local governments in Japan are based on indirect democracy and giving residents the right to elect and be elected as members of the local assembly and chief executives - Governors and Mayors. In addition to their indirect democracy, residents are allowed to participate directly in politics at the local level. Accordingly, residents of the area can request through a petition to enact the following: for example, revise or abolish local ordinances, perform audits of government activities, dissolve the assembly, or remove assembly members or the chief executive (CLAIR, 2019a, p. 17). According to the constitution, there is provision for any local government to hold a referendum on any law. However, difficulties arise in implementing the above two methods. Collecting signatures of voters for direct petitions is not an easy task, and on the other hand, holding a referendum is a time-consuming and costly process (M. S. Chowdhury \& Hossienie, 2012, p. 32).

\section{Partnership with Private Sector}

Most of the local governments collaborate with the private sector in Japan. In 2015, the public-private partnership (PPP) in Japan had made significant development. This trend was crucial regarding the service delivery of local governments. In the Japan-revitalization strategy, revised in 2015 by the Abe administration, the central government calls to local governments to provide the private sector with more opportunities to operate public (Sato \& Okatani, 2016, p. 1).

Yuzawa town is a tourist attraction in the Niigata Prefecture, and the infrastructure needs to be developed. However, this city office alone cannot develop that area. Hence, in 1970, the city officials decided to improve this city with the private sector, and the infrastructure of Yuzawa town was developed. Due to the involvement of the private sector, Yuzawa government could improve the fiscal balance and continue a fiscal surplus since 1978. The public sector founded the trial "Kan ritsu min ei" hospital, managed by the private sector. This hospital, started in 1986 with the public and private sector, was developed to facilitate town people and foreigners. Accordingly, this hospital contributes to the tourism industry in the Yuzawa town and the region. The development of Yuzawa town was a joint venture with several other private sectors, and some of them are mentioned below:

Snowing region: Gala-Yuzawa skiing area in collaboration with JR East Japan, Transportation infrastructure (Turnpike \& Shinkansen) for the tourism destination; 
Hot spring resort: campaign for a tourism destination in Tokyo by the public sector, clean water and air; advantage for business activities of private companies including Japanese Sake and agro-industry companies.

Local government institutions could work with the private sector to gain many benefits. Many prefectures were transferred to the private sector such as Sendai Airport, Takamatsu Airport, Fukuoka Airport, Kobe Airport, New Kansai International Airport, Osaka International Airport, Toll roads, Water supply service, and sewage services (Sato \& Okatani, 2016, pp. 2-3). Subsequently, the local governments of Japan managed to provide an efficient and quality service to the people.

\section{Waste Management}

In Japan, the central government has enacted and revised laws to deal with the waste problems that have evolved over the years. The central government collaborates with local governments to manage this waste problem (Ministry of the Environment, 2014, p. 3). Today, Japan's environmental administration is centred on the ministry of the environment of the central government. However, currently, many local governments enact necessary environmental by-laws as a framework for advancing environmental administration (CLAIR, 2008, p. 15). Local governments have prepared flyers and handbooks and illustrated how to dispose of waste in plain language and distributed it to residents to promote understanding of the waste collection. Also, the staff of the provincial governments are amicable and explain to the Japanese and non-Japanese residents about waste recycling in their respective areas.

In terms of waste management, the central government is primarily responsible for formulating basic policies, establishing waste management standards, the establishment of outsourcing standards, setting facility standards, and technical development and gathering information. In Japan, the prefectures perform several tasks with the support of the central government on waste management. These include the formulation of waste management plans, getting permission for the establishment of waste management facilities and industrial waste management operations, and administrative regulations. Also, municipalities are responsible for preparing municipal waste management plans and municipal waste management (Ministry of the Environment, 2014, p. 20). In this way, the problem of waste, which is a major local problem in Japan, is dealt with closely by the central government and the local governments. 


\section{Conclusion}

The Japanese government system consists of three layers as the central government, prefectural governments, and municipal governments. Thus, Japan's prefectures and municipalities are recognized as local governments, and these institutions can engage in the delivery of local services as active political functional bodies with constitutional recognition. This article was designed to provide an empirical analysis of the performance of local service delivery under local governments in Japan. Concerning this objective, the theoretical and practical application of decentralization and local service delivery was discussed in the literature review.

The use of secondary data to analyse the revenue and expenditure of the local governments of Japan helped to identify its correlation. Karl Pearson's correlation value of revenue and expenditure is 0.979 , and its Pvalue is 0.000 . Also, there are two types of hypotheses; $\mathrm{H}_{0}$ : There is no significant relationship between Revenues and Expenditure, and $\mathrm{H}_{1}$ : There is a significant relationship between Revenues and Expenditure. Here, the calculated p-value is less than 0.05. It allows us to conclude with $95 \%$ confidence, that there is a significant relationship between Revenues and Expenditure.

Prefectural and municipal governments, along with the central government, provide services such as security, physical infrastructure development, education, welfare, health care, and economic development of the country. However, as a developed country, Japan's local governments have shown positive features, both fiscal capacity and power functional abilities.

Services such as waste management and sanitation are better implemented at the local level. Moreover, the highest value of local government spending in Japan is for public welfare. Education services, civil engineering, and general administration rank second, third, and fourth, respectively. As a result, Japan-revitalization strategy, revised in 2015 by the Abe administration, has made significant progress with the introduction of the Public-Private Partnership (PPP) to Japan's local governments. However, Japan's local governments are getting closer to the people and play a role in providing many services to them in their daily lives. 


\section{References:}

1. Amarasinghe, R. (2011). Asymmetrical Devolution: Understanding The Spanish Experience. In R. Amarasinghe \& J. Wickramaratne (Eds.), Power S haring The International Experience (pp. 144-167). Rajagiriya: Institute for Constitutional Studies.

2. Aoki, I. (2008). Decentralization and Intergovernmental Finance in Japan. PRI Discussion Paper Series, Japan, Policy Research Institute, Ministry of Finance., p.1-78.

3. Barrett, B. F. D. (2000). Decentralization in Japan: Negotiating the Transfer of Authority. Japanese Studies, 20(1), p.34-48.

4. Bessho, S.-I. (2006). Case Study Of Central And Local Government Finance In Japan. ADBI Working Paper Series, p.1-24.

5. Cheema, G. S., \& Rondinelli, D. A. (1983). Implementation Decentralization Policies: An Introduction. In G. S. Cheema \& D. A. Rondinelli (Eds.), Decentralization and Development, Policy Implementation in Developing Countries (pp. 9-34). New Delhi: Sage Publications.

6. Chowdhury, M. S., \& Hossienie, C. A. A. (2012). Quest for an Effective and Efficient Local Government: Local Government in Japan and Policy Implication for Local Government in Bangladesh. Bup Journal, 1(1), p.23-43.

7. Chowdhury, S. (2017). Democratisation of Local Government Planning in Bangladesh. Commonwealth Journal of Local Governance(20), p.115-134.

8. CLAIR. (2008). Environmental Administration in Japan and the Role of Local Governments. Papers on the Local Governance System and its Implementation in Selected Fields in Japan(7), p.1-34.

9. CLAIR. (2019a). Local Government in Japan Council of Local Authorities for International Relations, p.1-56.

10. CLAIR. (2019b). Local Government in Japan (2019 revised edition). Council of Local Authorities for International Relations, Japan, p.158.

11. Davoodi, H., \& Zou, H.-f. (1988). Fiscal Decentralization and Economic Growth: A Cross-Country Study. Journal of Urban Economics, 43, p.244-257.

12. Eigeman, J. (2007). Service Delivery, a Challenge for Local Governments. The Hague, the Netherlands: VNG International.

13. European Commission. (2007). Supporting Decentralisation and Local Governance in Third Countries. Luxembourg: European Commission. 
14. Herath, T. N. (2009). Decentralization of Governance and Economic Development: the Sri Lankan Experience after Establishment of Provincial Councils. South Asia Economic Journal, 10(1), p.157-185.

15. Hossain, A. (2005). Administrative Decentralization: A Framework for Discussion and its Practices in Bangladesh. Department of Public Administration,University of Rajshahi, p.1-43.

16. Ikawa, H. (2008). 15 Years of Decentralization Reform in Japan. $U p$ to-date Documents on Local Autonomy in Japan, 4, p.1-29.

17. Iqbal, F. (2001). Evolution and Salient Characteristics of the Japanese Local Government System. World Bank Paper(37179), p.1-22.

18. Iritani, J., \& Tamaoka, M. (2005). Japanese Fiscal Structure between Central and Local Governments - Welfare Assessment of the Trinity Reform of Japan. Government Auditing Review, 12, p.23-40.

19. Islam, T., \& Fujita, K. (2012). Dimension of Decentralization Process and Rural Local Government in India: A Comparison with Bangladesh. Kyoto Working Papers on Area Studies(130), p.1-26.

20. Japan Statistical Hand Books. (2009-2019). Japan Statistical Hand Books. Japan: Statistics Bureau Ministry of Internal Affairs and Communications.

21. Japan Statistical Year Books. (2005-2016). Japan Statistical Year Books. Japan: Statistics Bureau, Ministry of Internal Affairs and Communications.

22. Japan Statistical Year Books. (2008-2019). Japan Statistical Year Books. Japan: Statistics Bureau Ministry of Internal Affairs and Communications.

23. Kauzya, J. M. (2007). Political Decentralization in Africa: Experiences of Uganda, Rwanda, and South Africa. In G. S. Cheema \& D. A. Rondinelli (Eds.), Decentralizing Governance Emerging Concepts and Practice (pp. 75-91). Washington, D.C.: Brookings Institution Press.

24. Kayama, M. (2007). Recent Local Financial System Reform (Trinity Reform). Up-to-date Documents on Local Autonomy in Japan(2), p.123.

25. Kimura, S. (2015). Goals and reforms of current Japanese local tax system. Hitotsubashi Journal of Law and Politics, 43, p.17-48.

26. Kimura, S. (2017). Japanese Local Tax System and Decentralization. In N. S. Cooray \& S. Abeyratne (Eds.), Decentralization and Development of Sri Lanka Within a Unitary State (pp. 329-364). Singapore: Springer Publishing Company.

27. Lewis, B. D., Mcculloch, N., \& Sacks, A. (2016). Measuring Local Government Service Delivery Performance: Challenges and 
(PARTIAL) Solutions in Indonesia. Journal of International Development, 28(5), p.808-817.

28. Lin, J. Y., \& Liu, Z. (2000). Fiscal Decentralization and Economic Growth in China. Economic Development and Cultural Change, 49(1), p.1-21.

29. Meenakshisundaram, S. S. (1994). Decentralization in Developing Countries. New Delhi: Concept Publishing Company Ltd.

30. Michihiro, K. (2010). Local Government in Japan. Council of Local Authorities for International Relations, p.1-60.

31. Ministry of the Environment. (2014). History and Current State of Waste Management in Japan. Information Site for International Development of Japanese Recycling Industry,, p.01-30, https://www.env.go.jp/en/recycle/smcs/attach/hcswm.pdf.

32. Mudalige, P. W. (2019). The Discussion of Theory and Practice on Decentralization and Service Delivery. European Scientific Journal, 15(14), p.115-135.

33. Mugabi, E. (2005). Decentralization for Good Governance: Policies, Legal Frameworks and Implementation Strategies. In G. Bertucci (Ed.), Decentralized Governance for Democracy, Peace, Development and Effective Service Delivery (pp. 22-33). New York: UN: Division for Public Administration and Development.

34. Muriu, A. R. (2013). Decentralization, Citizen Participation and Local Public Service Delivery-A study on the Nature and Influence of Citizen Participation Ondecentralized Service Delivery In Kenya. Universität Potsdam, p.1-80.

35. OECD. (2018). Subnational Governments in OECD Countries: Key Data 2018 (edi). Paris: OECD.

36. OECD. (2019). Asymmetric Decentralisation: Policy Implications in Colombia. Colombia: Secretary-General of the OECD.

37. Olsen, H. B. (2007). Decentralisation and Local Governance Module 1: Definitions and Concepts. Concept Paper on Decentralisation and Local Governance, p.1-25.

38. Patwar, N. (2014). Local Government Decentralization: A Comparative Study of Bangladesh and Japan. Assignment, Department of Public Administration, University of Dhaka, Bangladesh, p.1-38, www.academia.edu/11804882/Local_government_Decentralization_ A_comparative_study_of_Bangladesh_and_Japan.

39. Piccone, T. (2016). Five Rising Democracies: And the Fate of the International Liberal Order. Washington, D.C: Brookings Institution Press. 
40. Rahim, F. u., \& Shirazi, N. S. (2018). Fiscal Decentralization and Citizen's Satisfaction from Local Public Service Delivery In Pakistan. International Journal of Ethics and Systems, 34(1), p.122-142.

41. Rondinelli, D. (1981). Government Decentralization in Comparative Perspective: Theory and Practice in Developing Countries International Review of Administrative Sciences, 47( 2 ), p.133-145.

42. Rondinelli, D. (1999). What and Why.. What is Decentralization. In J. Litvack \& J. Seddon (Eds.), Decentralization Briefing Notes (pp. 15). Washington, D.C: World Bank.

43. Sasaki, A. (2014). Local Self-Government in Japan. Ministry of Internal Affairs and Communications, Japan.

44. Sato, M., \& Okatani, S. (2016). Recent Developments in PublicPrivate Partnerships In Japan. Energy \& Infrastructure, p.1-4.

45. Shiba, H. (2008). Comparative Local Governance: Lessons from New Zealand for Japan. (Doctor of Philosophy), School of Government, Victoria University of Wellington.

46. Shirai, S. (2004). The Role of the Local Allocation Tax and Reform Agenda in Japan -Implication to Developing Countries. Policy and Governance Working Paper Series, 32, p.1-36.

47. Smith, L. D. (2001). FAO Agricultural Policy and Economic Development Series, Reform and Decentralization of Agricultural Services: A Policy Frame Work. Rome: Agriculture and Economic Development Analysis Division, Food and Agriculture Organization of the UnitedNations.

48. Statistical Handbook of Japan. (2019). Statistical Handbook of Japan. Japan: Statistics Bureau Ministry of Internal Affairs and Communications.

49. Statistical Handbooks of Japan. (2018, 2019). Statistical Handbook of Japan. Japan: Statistics Bureau Ministry of Internal Affairs and Communications.

50. Steiner, S. (2005). Decentralisation and Poverty Reduction: A Conceptual Framework for the Economic Impact. Working Papers Global and Area Studies, p.1-30.

51. Szabo, S. R. (2017). The Empirical Relationship between Fiscal Decentralization and Economic Growth: A Review of Variables, Models and Results. Management Research and Practice, 9(2), p.4766.

52. Thießen, U. (2003). Fiscal Decentralisation and Economic Growth in High-Income OECD Countries. Fiscal Studies, 24, p. 237-274.

53. Uddin, M. N. (2013). Towards Good Urban Local Governance in Bangladesh: Lessons learnt from Japanese Local Government System 
to Overcome the Challenges. Journal of Local Self-Government, 11(4), p.933-953.

54. UNCRD. (2014). Japanese Administrative System. UNCRD/AIT-VN Training Course on Management and Administration of Local Government Institutions for Bangladesh, p.1-22.

55. Utomo, T. W. W. (2009). Balancing Decentralization and Deconcentration: Emerging Need for Asymmetric Decentralization in the Unitary States. Discussion Paper, Nagoya University, Nagoya(No.74), 1-30.

56. Vazquez, J. M., Peñas, S. L., \& Sacchi, A. (2015). The Impact Of Fiscal Decentralization: A Survey. GEN Working Paper, p.1-30.

57. Woller, G. M., \& Phillips, K. (1998). Fiscal Decentralisation and LDC Economic Growth: An Empirical Investigation. Journal of Development Studies, 34(4), p.139-148.

58. Work, R. (2002). Overview of Decentralization Worldwide: A Stepping Stone to Improved Governance and Human Development. United Nations Development Programme, New York, p.1-20.

59. Yagi, K. (2004). Decentralization in Japan. Policy and Governance Working Paper Series(30), p.1-30.

60. Zhao, Z. J. (2009). Fiscal Decentralization and Provincial-Level Fiscal Disparities in China: A Sino U.S. Comparative Precepective Public Administration Review, 69, p.668-674. 


\section{Annexe 1: Administrative Organization of Prefecture}

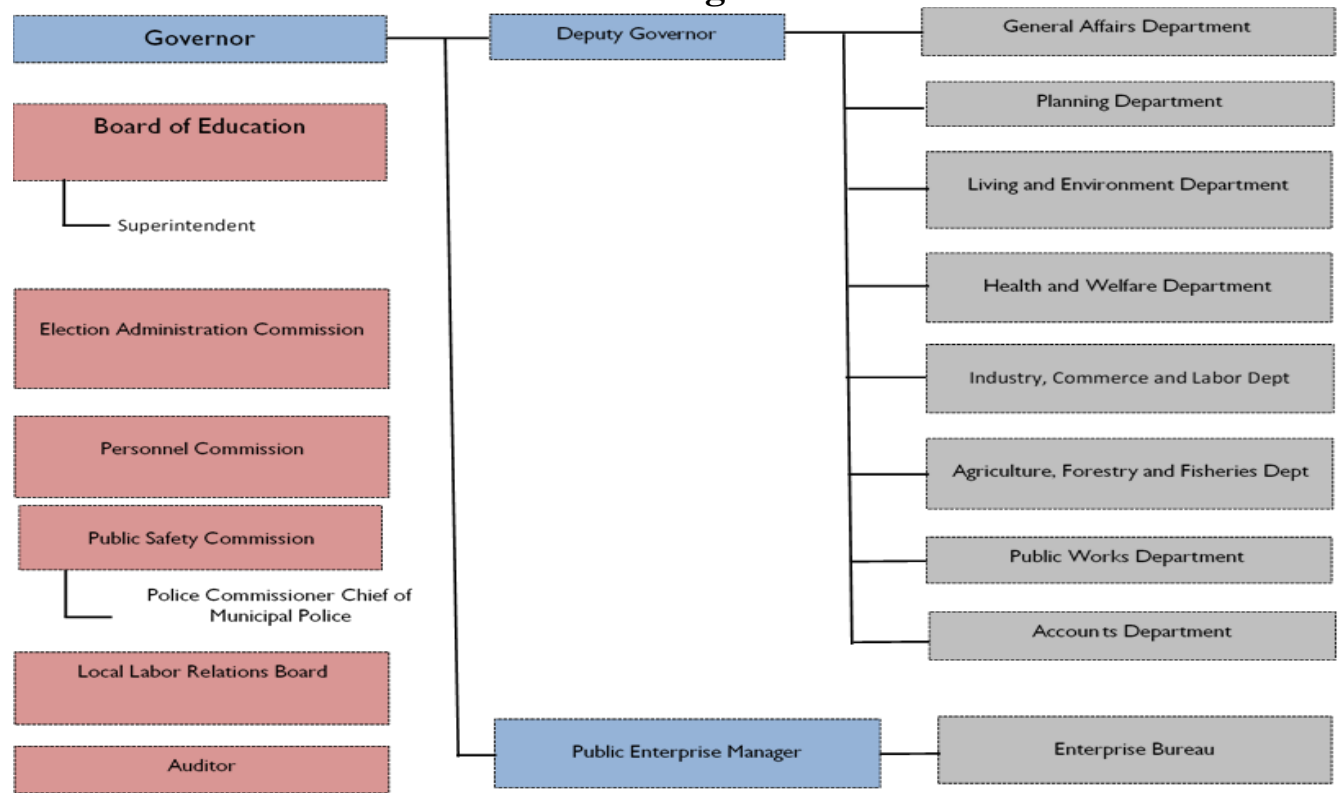

Source: (Sasaki, 2014)

\section{Annexe 2: Administrative Organization of Municipality}

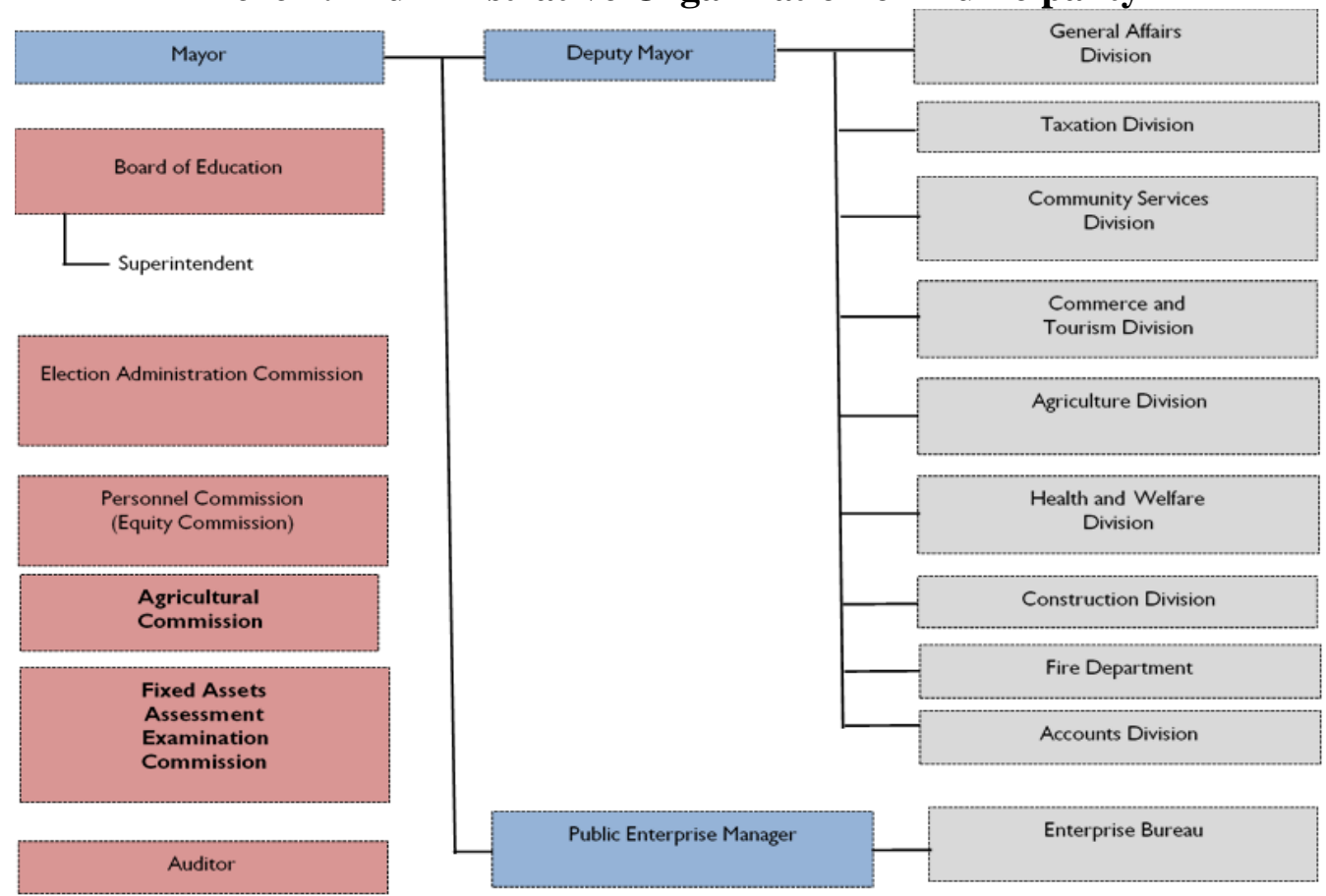

Source: (Sasaki, 2014) 